\title{
Past and Present Distribution of Walruses in Svalbard
}

\author{
IAN GJERTZ' and ØYSTEIN WIIG ${ }^{1}$
}

(Received 30 April 1992; accepted in revised form 9 June 1993)

\begin{abstract}
Walruses were once very abundant in the Svalbard archipelago. However three and a half centuries of commercial exploitation had caused the walrus to be on the verge of extinction in this region when it finally was totally protected in 1952. Since the mid-1980s walruses have again been commonly seen in parts of Svalbard. Based on information from literature, interviews and field observations, we attempt to identify in which areas of Svalbard, both historically and presently, walruses most frequently are observed and indicate the presence of all known walrus haul-out sites in the archipelago. Our study shows that walruses most frequently have been encountered during summer in four main areas. The results further indicate that walruses in Svalbard are predominantly males. Females and calves are, when encountered, mostly found in the extreme northeast part of Svalbard, neighboring the Russian archipelago Franz Josef Land. We discuss the possibility of migrations occurring between these two geographical areas and suggest that walruses in these two archipelagos are part of one common stock.
\end{abstract}

Key words: walrus, Odobenus rosmarus, Svalbard, distribution

\begin{abstract}
RÉSUMÉ. Les morses abondaient autrefois dans l'archipel du Svalbard, mais trois siècles et demi d'exploitation commerciale avaient amené cette espèce animale au bord de l'extinction dans cette région, quand elle fut finalement déclarée espèce protégée en 1952. Depuis le milieu des années 80, les morses sont de nouveau observés couramment dans diverses parties du Svalbard. En s'appuyant sur des documents publiés, des interviews et des observations sur le terrain, on tente d'identifier les régions du Svalbard où l'on a observé ces animaux, dans le passé et de nos jours, et d'indiquer la présence de tous les sites connus où abordent les morses dans l'archipel. Notre étude révèle qu'on a aperçu le plus souvent les morses durant l'été dans quatre grandes régions. Les résultats indiquent en outre que les morses du Svalbard sont en majorité des mâles. L'observation de femelles et de petits a été faite en majorité aux confins nord-est du Svalbard, jouxtant l'archipel russe François-Joseph. On discute de la possibilité de migrations se produisant entre ces deux régions géographiques et on suggère que les morses peuplant ces deux archipels font partie d'une population commune.
\end{abstract}

Mots clés: morse, Odobenus rosmarus, Svalbard, répartition

Traduit pour le Journal par Nésida Loyer.

\section{INTRODUCTION}

In 1604 the first walrus (Odobenus rosmarus) hunt occurred in Svalbard (Poole, 1604-09). This marked the beginning of the onslaught on the walrus population in this arctic archipelago. Centuries of walrus hunting finally caused the once vast herds to be on the verge of extinction (Norderhaug, 1969), when they finally were given total protection in 1952 (Anonymous, 1952). It is difficult to assess the size of the original population prior to hunting, but it must have been enormous (Reeves, 1978). The walrus was, according to Beechy (1843), more numerous at Svalbard in his day than it was in Baffin Bay or the Bering Strait. Today we finally see a significant increase in the walrus population in Svalbard (Gjertz and Wiig, unpubl. data).

Svalbard (Fig. 1) is the name of the group of islands situated between $74-81^{\circ} \mathrm{N}$ and $10-35^{\circ} \mathrm{E}$. Viktoria Island $\left(80^{\circ} 15^{\prime} \mathrm{N}\right.$, $36^{\circ} 45^{\prime} \mathrm{E}$ ), which is Russian territory and administered under Franz Josef Land, is here considered part of the Svalbard archipelago because the island lies closer to Kvitøya than to Franz Josef Land.

In summer there is little drift-ice along the west coast of Spitsbergen. However the areas north and east of Nordaustlandet have large amounts of ice and are often unnavigable even in summer. Svalbard is a high arctic archipelago without an indigenous human population. Apart from sporadic trappers and occasional scientific wintering expeditions, predominantly on the western and northern coasts of Spitsbergen, the first settlements were established at the beginning of this century. They were based on mining and mostly found in the fiords on the west coast (Hoel, 1966).
For large parts of the year most of Svalbard is inaccessible to ship traffic. This is true in spite of the fact that the sea off the west coast of Spitsbergen is one of the world's northernmost navigable arctic waters in winter. Before the development of modern ice-class vessels, navigation in Svalbard waters was mostly limited to the months of May to September. Even though the earliest explorers and whalers navigated parts of Svalbard's eastern and northern waters, the first known circumnavigation of Svalbard occurred as late as 1863. The neighboring archipelago Franz Josef Land (Russia) was discovered in 1865 (Horn, 1930). Svalbard's easternmost island, Kvitøya, first seen in 1707, was rediscovered in 1876, and nearby Viktoria Island (Russia) was discovered in 1898 (Hoel, 1944). These inaccessible areas proved to be inhabited by large numbers of walruses, and as hunting declined in the western part of the archipelago the hunters moved steadily eastwards in search of prey.

The largest shallow-water area $(<100 \mathrm{~m})$ in Svalbard is found from Bjørnøya to Tusenøyane and Edgeøya (Fig. 1). The second largest area is off the northern coasts of Nordaustlandet. If Kvitøya and Viktoria Island are added to this, we here have one large, discontinuous shallow-water area. The strait between Viktoria Island and Franz Josef Land is 300-500 $\mathrm{m}$ deep, and at Franz Josef Land there is deep water right up to the coast. The strait between Greenland and Svalbard is very deep, on average about $3000 \mathrm{~m}$. The areas with the most shallow water are clearly in eastern Svalbard. At present it is not known if these large shallowwater areas differ from the shallow areas along Spitsbergen's west coast in regard to quality as feeding habitat. Walruses

\footnotetext{
'Norwegian Polar Research Institute, P.O. Box 5072 Majorstua, N-0301 Oslo, Norway
}

(C)The Arctic Institute of North America 
are bottom feeders and are primarily found in areas of relatively shallow water (Fay, 1981). In summer they moult, at which time they often are seen on land or on ice. They are site tenacious and annually return to the same haul-out sites on land. This was a major cause of their decline in Svalbard, since hunters therefore knew where to find them. They were slaughtered either at their haul-out sites or on ice floes or harpooned in the water (Hoel, 1949). Bones decay very slowly in the High Arctic and even today indicate the sites where walruses were butchered several hundred years ago.

Lønø (1972) summarized historical catches of walruses in Svalbard and the adjacent European arctic waters and indicated the areas in Svalbard considered best for hunting. Based on catch statistics he postulated that the Svalbard stock must have been composed of partially stationary groups that had some contact with each other. Other authors have indicated the areas of Svalbard in which walrus observations have been most numerous in the latter part of this century (Norderhaug, 1969; Øritsland, 1973; Born, 1984). This information either indicates the distribution in the present early stages of a recovering stock or possibly reflects the distribution of observational effort. Hitherto no thorough review of known walrus observations in Svalbard has attempted to map the past and present distribution of walruses in Svalbard. The present study attempts to do this on the basis of several different sources of information.

\section{METHODS}

When reviewing historical sources, the number, age and sex of the observed animals were noted when possible. The exact location of the observations is often difficult to pinpoint. All records of walrus observations were therefore, when possible, classified according to month and location within quadrangles on a polar stereographic map of Svalbard with adjacent seas, with true scale along the $78^{\circ}$ parallel, each quadrangle being $5^{\circ}$ longitude and $1^{\circ}$ latitude. Due to deep fiords, especially on Spitsbergen, coastlines from different parts of Svalbard are in some instances found within the same quadrangle. To avoid misinterpretation in these cases, observations from fiords that stretch over more than one quadrangle are registered as being made in the mouth of the fiord.

The Norwegian Polar Research Institute has Scandinavia's largest collection of polar literature. All books, trappers' diaries, sealing vessel logbooks, journals and scientific literature concerning Svalbard were searched for information on observations of walruses. Arktisk Forening's (Arctic Society, Tromsø) collection of trappers' diaries was similarly searched.

Most of Svalbard is uninhabited, and outside the summer season coastal waters are rarely travelled by ships other than fishing vessels. A questionnaire requesting information on walrus observations and offering a modest reward for such information was sent to 92 Norwegian fishing vessels registered by the Norwegian Coast Guard as operating within Svalbard waters. In addition, advertisements requesting information on walrus observations were placed in Svalbard's local

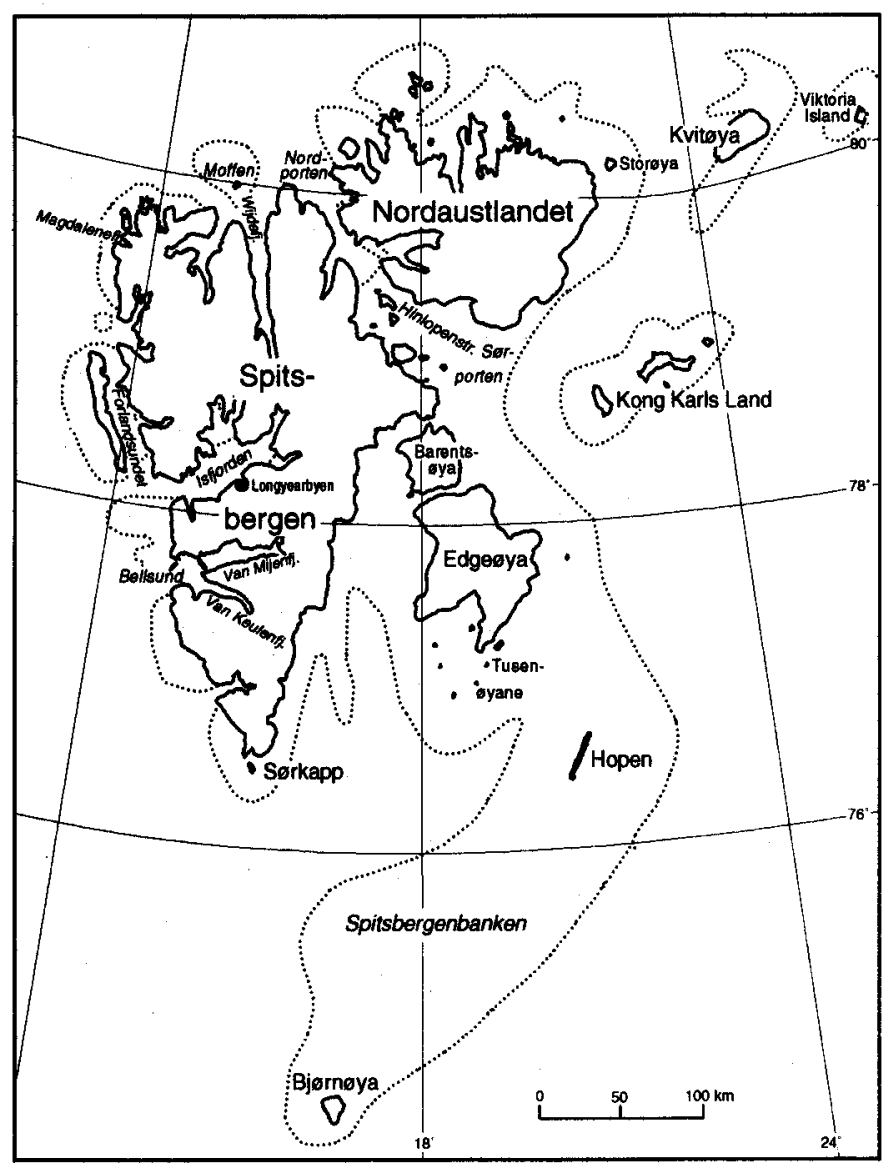

FIG. 1. Map of Svalbard with surrounding seas. Areas with sea depths less than $100 \mathrm{~m}$ are hatched.

newspaper and in two different Norwegian newspapers for fishermen.

Opportunistic interviews were conducted with residents of Svalbard and tourists, requesting information on walrus observations and the location of former haul-out sites. Similarly, interviews were conducted with members of Arktisk Forening who were retired sealers with considerable knowledge of Svalbard dating back to the 1920s. Walrus observations from the fauna databases of Havforskningsinstituttet (Institute of Marine Research), Sysselmannen (Governor of Svalbard) and Norwegian Polar Research Institute were put at our disposal. The two former databases provide opportunistic observations, while the latter combines opportunistic observations with walrus surveys. In addition we used information from our own walrus surveys conducted from 1987 to 1991 at Edgeøya and Tusenøyane by foot, helicopter (Aerospatial AS $350 \mathrm{~B}$ ) and rubber dinghy. The presence of former haul-out sites, as well as haul-out sites now in use, were noted based on observations of skeletal remains, drag marks and hauled-out animals.

Any single walrus observation may appear in several different sources of information. This is especially true for observations recorded after 1952 (Norderhaug, 1969; Lønø, 1972; Øritsland, 1973; Born, 1984; etc). We have therefore compared these sources to avoid counting the same observation twice. The results of our walrus surveys for 1987-91 are included in this study. This survey is to a large degree 
based on daily observations of walruses at haul-out sites. To treat these observations similarly to those from the review, such walruses are registered as one observation for each day the herd was present at the haul-out site.

\section{RESULTS}

A summary of all walrus observations included in this study, from 1604 to 1991, is given in Figure 2. The numbers indicate only the number of walrus observations within each quadrangle and do not give any information on the number of animals observed. Each quadrangle is assigned a code number according to vertical letters $(\mathrm{A}-\mathrm{H})$ and horizontal figures (1-10). Figure 2 shows that most observations have been made in the southern Edgeoya-Tusenøyane area (E6-F6). Apart from this area, most observations have been made in the area from northwestern Spitsbergen along northern Spitsbergen and along the north coast of Nordaustlandet (D4, C4, C5, B4-B7).

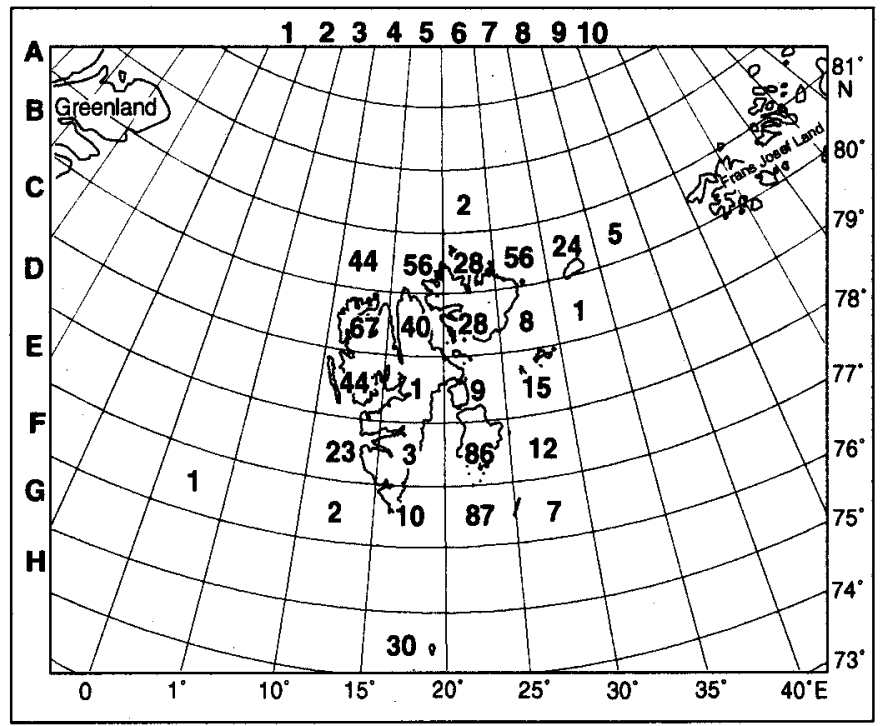

FIG. 2. Quadrangle map of Svalbard with surrounding seas. Numerals indicate total number of walrus observations within each quadrangle. Each quadrangle is identified by a vertical letter $(\mathrm{A}-\mathrm{H})$ and a horizontal number (1-10). Data based on observations from the following chronological list of sources: Poole, 1604-09, 1610, 1611, 1612; Hudson, 1607; Edge, 1609-22; Baffin, 1613; Fotherby, 1613, 1614; Gerritsz, 1613; v. der Brugge, 1634; Martens, 1671; Zorgdrager, 1720; Phipps, 1774; Scoresby, 1820, 1823; Parry, 1828; Keilhau, 1831; Eschels, 1836; Schare, 1837; Beechy, 1843; Lamont, 1860, 1861; Chydenius, 1865; Petermann, 1872; Lamont, 1876; Wells, 1876; Hansen, 1882-1912; Anonymous, 1884-1910; Kükenthal, 1890; Hamberg, 1894; von Barry, 1894; Pike, 1894, 1897; Kræmer, 1895-1916; Carlheim-Gyllensköld, 1900; Nathorst, 1900; Röner and Schaudinn, 1900; Hagerup, 1901; Kolthoff, 1901, 1903; Bengtsen, 1903-34; Pedersen, 1907, 1912; Hansen, 1913; Paulsen, 1917-22; Isachsen, 1919; Nansen, 1920; Bjørnes, 1922; Kræmer, 1922; Olsen, 1924; Binney, 1925; Oxås, 1925; Lumholtz, 1926; Svendsen, 1927, 1928, 1930; Sæther, 1929; Ette, 1930; Andree' et al., 1930; Johansen, 1932-34; Lodgaard, 1934; Åm, 1935-37; Eide, 1936; Glen and Croft, 1937; Godfrey, 1938; Rehfus-Oberländer, 1941; Ytreberg, 1946; Berset, 1953; Oxås, 1955; Sørensen, 1958; Tollén, 1960; Norderhaug, 1969; Møllen, 1971; Lønø, 1972; Benjaminsen et al., 1973; Øritsland, 1973; Johansson, 1975; Larsen, 1983; Born, 1984; Jepsen, 1986; Krawczyk and Weslawski, 1987; Kristiansen, 1989; Institute of Marine Research Marine-Mammals-DataBase, 1967-91; Norwegian Polar Research Institute Fauna-Data-Base, 1982-91; Governor of Svalbard Fauna-Data-Base, 1987-91.
These observations are specified by century in Figure 3. This clearly shows that the majority of observations from Bjørnøya (H5) are from before 1800 (Fig. 3a). Prior to the 19th century there are few known observations from eastern Svalbard (Fig. 3a). The high number of observations from the northeast corner of Nordaustlandet (B7) in the 19th century are from after 1863, the year Svalbard was first circumnavigated. Figure 3d depicts only observations from after 1982, the year in which the last published review of walrus observations in Svalbard was finished (Born, 1984). The area in Figure 2 with the most observations, southern Edgeøya-Tusenøyane (E6, F6), is partly due to the large number of observations in recent years (Fig. 3d).

When walruses were observed, the number of animals seen were rarely noted in the literature. However vague expressions such as "a large number," "numbers," "some walruses," etc., were often used. It is therefore difficult to determine in which area the largest numbers were seen. An attempt was made to identify specific observations of herds of more than 100 walruses. Such observations have been made to varying degree through the centuries throughout the archipelago. However four main areas are evident. These are: Bjørnøya (H5), southern Edgeøya-Tusenøyane (E6, F6), the Spitsbergen coast from Isfjorden to Wijdefjorden (D4, C4), and northeastern Nordaustlandet-Kvitøya (B7, B8). At Bjørnøya (H5) 10 such observations have been recorded, but only before 1800 . In southern Edgeøya-Tusenøyane (E6, F6) 16 observations have been made, but 10 of these are from after 1982. On the northwest coast of Spitsbergen (D4, C4) such herds have been seen 12 times, 8 of them before 1800 . From northeastern Nordaustlandet-Kvitøya (B7, B8) 11 observations of large numbers are known; 6 of these were recorded in this century. In 1920 the occurrence of a large herd was reported from Kong Karls Land (D7).

All observations in Figure 2 were also arranged by month. No observation is known from January, and the months February, March, November and December all had very few observations (a total of $6,2,3$ and 4 respectively). The months with most observations are July (33\%) and August (38\%). In these two months observations have been recorded throughout the archipelago. In the remaining months observations are limited but occur most often on the northwest coast of Spitsbergen (C4). The exception is September, when half of the observations (15 out of 30 ) are from southern Edgeøya (E6).

Females with calves have most often been seen along the northern shores of Spitsbergen (C4, C5), in northern Hinlopenstretet (C5), northeastern Nordaustlandet (B7), the Kvitøya area (B8) and southern Edgeøya-Tusenøyane (E6, F6). Before 1800 very few walrus calves were recorded in Svalbard (3). From the 19th century we have found 24 observations. Most of these (12) are from Hinlopenstretet (C5) and Nordporten (B5), while 5 are from southern Edgeøya (E6) and 3 from northwestern Spitsbergen (C4). We know of 11 observations from 1900 to 1982 . Four of these are from Kvitøya (B8), 1 from northeastern Nordaustlandet (B7) and 1 from Sørporten (C6). Another 2 are from northwestern Spitsbergen (C4), 2 from the Edgeøya area (E6, E7) and the last 1 from near Sørkapp (F5). From our own material we 


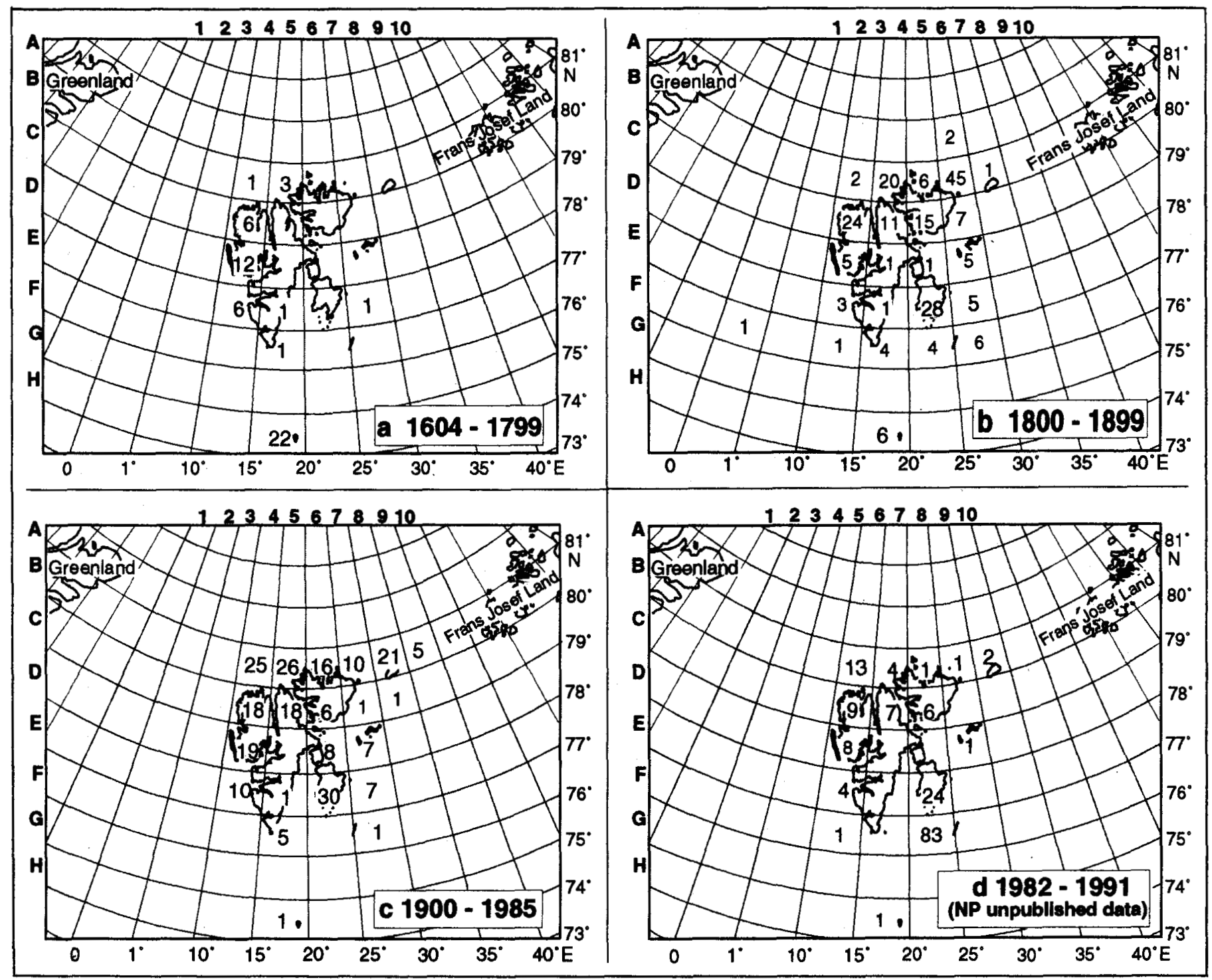

FIG. 3. Quadrangle maps of Svalbard with surrounding seas. Numerals indicate total number of walrus observations within each quadrangle within a specific time period: $\mathrm{A}=1604-1799, \mathrm{~B}=1800-99, \mathrm{C}=1900-85, \mathrm{D}=1982-91$ (previously unpubl. data). Data are from the same sources as in Figure 2. Each quadrangle is identified by a vertical letter $(A-H)$ and a horizontal number $(1-10)$.

have found occasional calves in the northwestern part of Spitsbergen (C4), in Nordporten (B5), at Kvitøya (B8) and southern Edgeøya-Tusenøyane (E6, F6). The only area where females/calves were seen in numbers was at Kvitøya in August 1987, when dispersed groups of females with calves estimated to total more than 500 individuals were seen. Females with calves, either calves of the year or one-yearolds, have most frequently been observed in July and August, the months when most walrus observations are recorded in Svalbard.

All known past and present haul-out sites, excluding Bjørnøya, are indicated in Figure 4. However, only the areas of Barentsøya, Edgeøya and Tusenøyane have been thoroughly investigated. Apart from Bjørnøya and most of the west coast of Spitsbergen, where large parts have been checked quite thoroughly, most of the rest of Svalbard has been investigated more opportunistically. Kong Karls Land is a highly protected conservation area with year-round restriction of access, and we do not have information from this area. We do, however, know that walruses are found here (Hoel, 1931). Most of the southern coast of Nordaustlandet is one long glacier front without potential haul-out sites.

We received only 4 replies to our 92 questionnaires. Three of these contained useful information.

\section{DISCUSSION}

\section{Historical Review}

Several factors influence the results of the present study and may bias the results. Even though the Norwegian Polar Research Institute has Scandinavia's largest collection of literature on Svalbard, it is by no means complete. Besides Norwegian and other Scandinavian activities, there has historically been an extensive Russian, Dutch, German and English presence in Svalbard. Whereas the three latter nationalities mostly were summer visitors to the islands, the 
Russians had well-planned wintering parties throughout large parts of the archipelago through the 18th century and until 1850. Because of language barriers and the fact that most of the Russian files were kept at the closed monastery in Solovietskiye, we have made no attempt to include these in the present study. Literature in French and Latin has only been searched to a minor degree. There is also a significant amount of older English and Dutch literature that we have not had access to. In any event, a survey of older literature will never be complete. We recognize that we have missed references, either due to the fact that we were not aware of the literature or because we happened to overlook the part in a text dealing with walruses. However we believe this to be of minor significance, since the data presented in this study are sufficient to indicate the areas that are important walrus habitat. This is especially true when this information is compared with present observations from Svalbard and information on walrus biology in general. Some of the information found about walruses in Svalbard is second-hand and vague about details. We generally chose to omit such observations from this study.

The best source of information on walruses is often sealingvessel logbooks, especially those from the late $1800 \mathrm{~s}$. At this time the more inaccessible parts of eastern Svalbard and Franz Josef Land were opening up to hunters. Many of the logbooks and diaries from this period were collected by the scientist Gunnar Isachsen but were destroyed in a fire before the First World War (Horn, 1930).

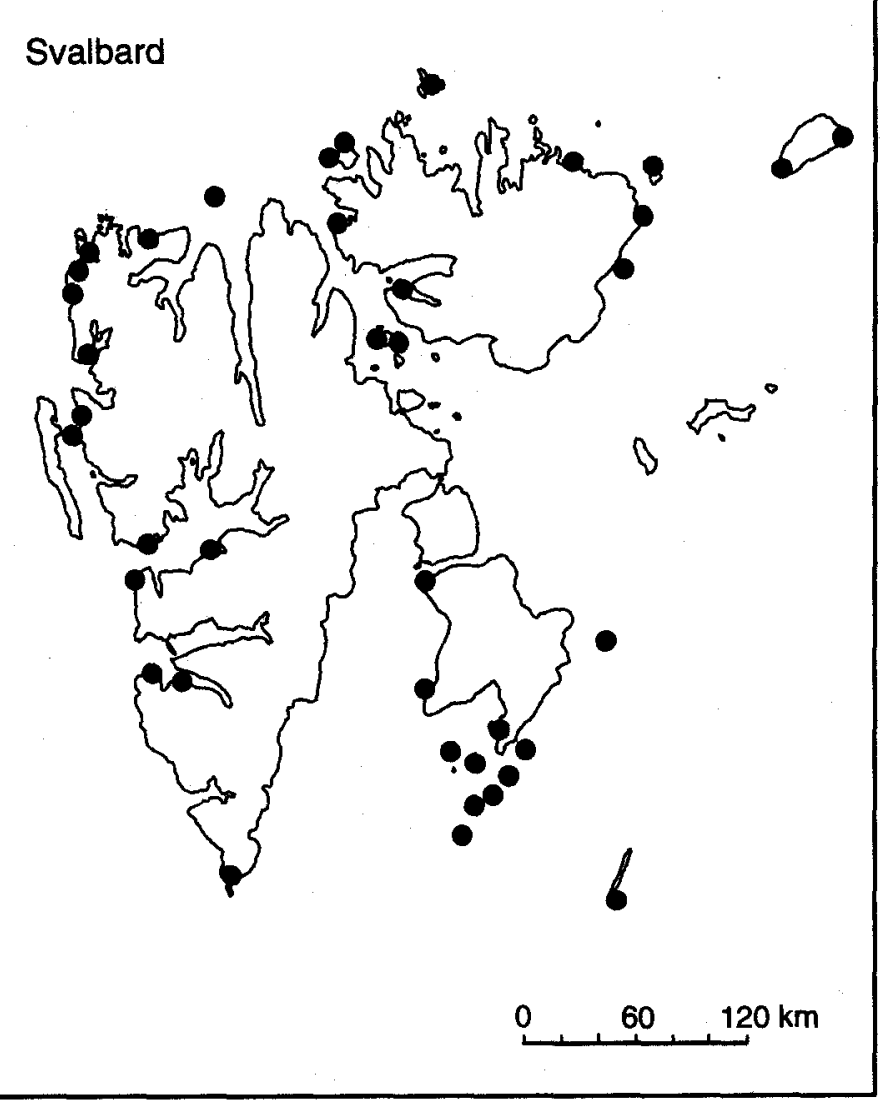

FIG. 4. Map of Svalbard, excluding Bjørnøya, indicating locations of known walrus haul-out sites. In addition there are two haul-out sites on Bjørnøya: one on the north tip and one on the east coast.
The limited number of replies from the fishing fleet was disappointing but not unexpected. There has in recent years been a dispute between authorities and scientists on one side and fishermen on the other concerning fishing quotas. Fishermen therefore suspect that information given to scientists will be used against them, and consequently they choose not to respond to questionnaires. When approached aboard their own vessel, one crew supplied information on walruses but did not answer the questionnaire. We therefore believe that the low number of answers may only be partly due to a lack of walrus observations.

\section{Walrus Observations}

By reviewing predominantly opportunistic walrus observations, it is difficult to assess the observational effort of the individual observer. It would appear that in most cases little effort was put into the observations. However some references contained very accurate observations, and these will therefore tend to bias the overall results. This also applies to the observations based on biological surveys conducted by the authors from the late 1980 s.

Because of the concentration of settlements in Svalbard, we have very limited information on the fauna in the more remote parts of the archipelago, especially in winter. By contrast the activity in summer has always been significant. This is the time of the greatest human activity in the archipelago, with the most people, i.e., observers, in the field. Then sealing, fishing, whaling, scientific and merchant vessels have frequented Svalbard waters, limited only by the extent of the pack-ice. For the period April-August Svalbard has the midnight sun, permitting continuous observations without interruption by darkness. Also, walruses moult in summer and spend a large part of their time basking on haul-out sites or ice. As they are more conspicuous at this time, it is not surprising that $71 \%$ of the observations in this study are from the the months July and August, the peak of summer.

Large herds of more than 100 walruses were more commonly seen before the numbers of walruses were significantly depleted. Bjørnøya (H5) is exceptional among the four main areas where herds of more than 100 walruses are recorded because walruses have not recolonized this island. All major observations of walrus at Bjørnøya were made before 1800 . We know that wintering trappers in the 1820 s caught a considerable number of walruses, but it is not known if these were from one or more herds (see Lonø, 1972, for a review). From the 20th century we know of only two observations of walrus, both single animals. The three remaining areas are all important walrus areas today. All three coincide with the areas where walruses are most frequently observed. One important area, Nordporten-Hinlopenstretet (B5, C5), has few records of large herds. The northwest corner of Spitsbergen is today the best-known area for walrus in Svalbard. This is partly due to the presence of the haul-out site on Moffen, a small island off the north coast (B4). This island is a walrus sanctuary, many people visit the area and we therefore receive many reports of walrus observations. The numbers of observed walruses are usually in the tens and rarely in the hundreds. 
Most of the observations of large herds from the northwest part of Spitsbergen are from before this century. Besides Moffen, Magdalenefjorden (C4) and Forlandsundet (D4) appear to be the most important areas. From southern Edgeøya (E6) and Tusenoyane (F6) we receive yearly reports of herds of more than 100 animals. This is the area with the most observations of large walrus herds and the most observations of walruses in Svalbard, in large part due to our yearly walrus surveys since 1987 in this area (see Fig. 3d). Although most effort has been put into counting walruses here, it is safe to assume that this is one of the two most important walrus areas in Svalbard, the other being the area from northeastern Nordaustlandet to Kvitøya (B7, B8) and Viktoria Island (B9). This latter area is however so remote it is rarely visited.

\section{Terrestrial Haul-out}

Haul-out sites have been located by searching for live animals or drag marks on land. In some parts of the archipelago we still find walrus remains after the former hunt. It is fairly easy to distinguish between skeletal remains of slaughtered animals and remains of those that have died a natural death. The former usually have the snout of the skull chopped off, or the premaxillary bone is chopped to get at the tusk. Due to the size and weight of a walrus, it is unlikely that the hunter would move it up on shore if it was caught on ice or in the water. It is therefore safe to assume that large collections of walrus bones on land represent slaughter sites, and not animals caught elsewhere.

The beach level in Svalbard is today fairly similar to that 400 years ago. The west coast of Spitsbergen is very stable, while the Edgeøya/Tusenøyane/Kong Karls Land area is slowly rising (Otto Salvigsen, pers. comm. 1990). Apart from factors such as erosion, sand drift and wave action, there are no physical reasons for the remains of walrus slaughter sites to disappear from Svalbard beaches. We therefore believe that we have discovered a significant part of the haul-out sites in the archipelago.

Though walruses are known to enter the fiords and are seen lying on fiord ice, we know of no haul-out sites deep within the major fiords on the west coast of Spitsbergen. Nøis (1960), however, mentions that there was a haul-out site near present-day Longyearbyen (D5). We have not been able to verify this, but in recent years walruses have been seen on the ice in areas close to this supposed site, and in October 1991 a single walrus hauled out on it. According to Gerritsz (1613), 200 walruses were caught in Van Keulenfjorden. This was on 23 June, a time when the ice is usually gone, which would indicate that there was a haul-out site here.

Russian hunters often based their wintering expeditions on catching walruses and would therefore settle near known haul-out sites. For most of Svalbard, except the inaccessible northeastern parts, the remains of Russian camps are often found in the vicinity of haul-out sites. We have little information on haul-out sites from the southeast coast of Spitsbergen. We do know that this coast was considered a poor hunting area by Norwegian trappers and that no remains of Russian dwellings have been found on this coast (G. Rossnes, pers. comm. 1991). We have searched this coast by air for haul-out sites without finding any, and in light of the lack of historical hunting grounds in this area we believe that none is found on this coast.

The haul-out site found on Hopen (F7) differs from the rest of those based on skeletal remains in that these animals probably died of natural causes, but we cannot determine when (Iversen, 1941). Sørensen (1958) mentions that numerous walrus tusks could be found along the beaches of Hopen. These were fossilized and probably very old. They do, however, indicate that walruses have been present at Hopen for a long time.

\section{Sexual Distribution}

Most of the reports of walruses from Svalbard fail to mention the sex of the animals. This is not surprising when dealing with animals often seen in the water, since it is difficult to distinguish between sexes. Calves are more often mentioned, possibly because they are clearly different from the adults. We have therefore chosen to group observations of females with those of calves, since the two stay close together.

We have only scant information on the distribution of females and calves in Svalbard. They seem to be centered on four main areas: northwestern Spitsbergen (C4), Hinlopenstretet (C5), northeastern Nordaustlandet-Kvitøya (B7, B8) and southern Edgeøya-Tusenøyane (E6, F6). Apart from Chydenius (1865; see also Malmgren, 1863), Beechy (1843), Lamont (1861), Hansen (1882-1912), Jepsen (1986) and our own observations from 1987 , there have been no observations of large numbers of females and calves. Our observations from Svalbard after 1982 indicate that the only area where females and calves are found in significant numbers is the extreme northeastern part of the archipelago. The herds of walruses observed in other areas in summer are almost exclusively males, both adults and immatures (see also Born, 1984). This is in accordance with observations from the early literature (Kükenthal, 1890; Isachsen, 1919).

We know that from the turn of the last century sealing vessels caught large numbers of walruses in Franz Josef Land. In 1897 three sealers/whalers caught a total of 754 walruses here. Almost all the walruses were females and young, with a few young bulls (Southwell, 1898). The next year one of the ships caught 257 small walruses in this archipelago (Lubbock, 1937). Bruce and Clarke (1898) similarly found few males in Franz Josef Land in summer. This may indicate that the animals in Franz Josef Land are small, i.e., that they are predominantly females and calves. In 1990 and 1991 the authors undertook field trips to Franz Josef Land and found a large number of females and calves in the south-central parts of the archipelago. Compared with our knowledge on the walruses in Svalbard, this information suggests that there may be a close connection between the animals of these two neighboring archipelagos. Walruses are known to split up into male and female herds (Collett, 1911-12). Chydenius (1865) writes from Svalbard that walrus cows and calves are found in other areas than the bulls and that walrus hunters think the males travel in big herds out on the banks - i.e., shallow water far from land - while the females with calves habitually stay close to land and visit the fiords. It is therefore 
possible that the majority of walruses in Svalbard in summer are males from one common Svalbard-Franz Josef Land stock.

\section{Migrations}

If the walruses in these two neighboring archipelagos are from one common stock, they will necessarily have to undertake annual migrations. Some mention of such migration is found in the literature, but it is not well documented. Kræmer (1924) claims that walrus winter along the west coast of Svalbard and at Spitsbergenbanken. In spring they migrate north to Sørporten, Nordporten, Storøya, Kvitøya, Viktoria Island and Franz Josef Land. The return migration is in October. While wintering at the northwest corner of Spitsbergen, he claims to have observed herds of walruses migrating southward in October and northward in late April/early May. Lonø (1972) also mentions a possible southward migration in late autumn towards Edgeøya and Tusenøyane. This is based on information from wintering trappers. On the basis of catch statistics, Lønø (1972) dismisses the idea of an annual migration between the northeasterly parts of Svalbard and Franz Josef Land. Similarly he shows, also based on catch statistics, that even though walruses were exterminated in one area in Svalbard they could still be caught in other areas. He therefore suggests that the walrus population in Svalbard consisted of partially stationary groups that, because of close distances, had some contact with each other. Born (1984) discusses the possibility of walruses wintering in polynyas along the north coast of Nordaustlandet. He suggests that since walruses are first observed at Moffen late in July, they must come from wintering grounds farther away than Nordaustlandet - for example, from Franz Josef Land. Occasional sightings by trappers indicate that at least some walruses are present in Svalbard during winter. Satellite telemetry has indicated that at least some walruses are stationary at a polynya in Tusenøyane for up to nine months of the year, including the winter period (Wiig and Gjertz, unpubl. data).

We are presently conducting a satellite telemetry program on walrus in Svalbard and Franz Josef Land to determine if and where they migrate. At present, our results show that male Svalbard walruses make short, swift trips to Franz Josef Land and back (Wiig and Gjertz, unpubl. data). This supports the theory of a common Svalbard-Franz Josef Land stock (Born, 1984). Born and Knutsen (1992), using satellite telemetry in northeast Greenland, have shown that bull walruses from this area disperse out into Fram Strait, but they found no indication of a connection between the walruses in northeast Greenland (Dovebukt) and Svalbard. Although they predominantly encountered males in northeast Greenland, this suggests that these walrus must be part of a more widespread population.

Information from the ongoing satellite telemetry program in Svalbard, which is expected to finish in 1994, may shed light on Lønø's (1972) hypothesis that walruses in Svalbard consisted of partially stationary groups. It is, however, important to bear in mind that today the walruses in Svalbard constitute a recovering stock. Their distribution and behaviour may therefore differ from that found in Svalbard in former times.

\section{ACKNOWLEDGEMENTS}

We wish to thank Torger Øritsland for providing us with data on observations of walruses recorded by the Institute of Marine Research and for commenting on the manuscript. Observations of walruses from the Governor of Svalbard's Fauna-Data-Base were kindly provided by Sissel Aarvik. Kjell Huseby and Jørn Thomassen, Governor's Office, provided missing data on walrus haul-out sites on Edgeerya. Gustav Rossnes gave helpful comments concerning former Russian hunting activity on Svalbard. We thank Torbjørn Trulsen for access to Arktisk Forening's collection of trappers' diaries. We also wish to thank Randall Reeves for his thorough refereeing of the manuscript. This study was financed by the Norwegian Polar Research Institute and Norwegian Fisheries Research Council (NFFR).

\section{REFERENCES}

ANDREE', S.A., STRINDBERG, N., and FRAENKEL, K. 1930. Med Ørnen mot polen. Stockholm: Albert Bonniers Förlag.

ANONYMOUS. 1884-1910. Unpubl. logbook for the sealing vessel "Rivalen" for the years 1884-1910. Norwegian Polar Research Institute Library. Available at Norsk Polarinstitutt, Middelthuns gate 29, Postboks 5072 Majorstua, N-0301 Oslo, Norway.

1952. Fredning av hvalross. Kongelig Resolusjon (Royal Decree) 20. Juni 1952. Available from Fiskeridepartementet, Øvre Slottsg. 2, P.B. 8118 Dep., 0032 Oslo, Norway.

ÅM, P. 1935-37. Unpubl. diary. Norwegian Polar Research Institute Library, Diary \#1. Available at Norsk Polarinstitutt, Middelthuns gate 29, Postboks 5072 Majorstua, N-0301 Oslo, Norway.

BAFFIN, W. 1613. A Journall of the Voyage made to Greenland with sixe English ships and a Pinasse in the yeare 1613. Reprinted diary in Markham, C.R. 1881. The voyages of William Baffin 1612-1622. London: The Hakluyt Society. 38-53

von BARRY, R.R. 1894. Zwei fahrten in das nördliche Eismeer Spitzbergen und Novaja Zemlja unternommen von Sr. kön. hoheit Prinz Heinrich von Bourbon, Graf von Bardi an bord der österreichischen jachten "Fleur de Lys I und II" des k. und k. jacht-geschwaders in den jahren 1891 und 1892. Wien: Carl Gerhold's Sohn.

BEECHY, F.W. 1843. A voyage of discovery towards the North Pole, performed in his majesty's ships Dorothea and Trent, under the command of Captain David Buchan, R.N.; 1818. London: Richard Bentley.

BENGTSEN, K.J. 1903-34. I tredive aar rundt Svalbard. Unpubl. diary. Norwegian Polar Research Institute Library, Diary \#128. Available at Norsk Polarinstitutt, Middelthuns gate 29, Postboks 5072 Majorstua, N-0301 Oslo, Norway.

BENJAMINSEN, T., BERGFLØDT, B., and ØRITSLAND, T. 1973. Selundersøkelser i det nordlige Atlanterhav i 1973. (Seal investigations in the North Atlantic in 1973.) Fiskets Gang 59:853-863.

BERSET, O. 1953. Hilmar Nøis. Storjegeren fra Svalbard. Bergen: J.W. Eides Forlag.

BINNEY, G. 1925. With seaplane and sledge in the Arctic. London: Hutchinson \& Co.

BJØRNES, G. 1922. Unpubl. diary. Norwegian Polar Research Institute Library, Diary \#114. Available at Norsk Polarinstitutt, Middelthuns gate 29, Postboks 5072 Majorstua, N-0301 Oslo, Norway.

BORN, E.W. 1984. Status of the Atlantic walrus Odobenus rosmarus rosmarus in the Svalbard area. Polar Research 2:27-45.

BORN, E.W., and KNUTSEN, L.Ø. 1992. Satellite-linked radio tracking of Atlantic walruses (Odobenus rosmarus rosmarus) in northeastern Greenland, 1989-1991. Zeitschrift fur Säugtierkunde 57:275-287.

BRUCE, W.S., and CLARKE, W.E. 1898. The mammalia and birds of Franz Josef Land. Proceedings of the Royal Physical Society 14:78-112.

v. der BRUGGE, J.S. 1634. Journal or day-book kept by seven sailors during their wintering on Spitsbergen in Mauritius Bay, situated in Greenland, from the departure of the fishing-vessels of the Chartered Northern Company, in the Netherlands, on August 30, 1633 until the return of the aforesaid Vessels on May 27, 1634. Reprinted diary in: Conway, W. M. 1904. Early Dutch and English voyages to Spitsbergen 
in the seventeenth century. Hakluyt Society Second Series No. 11. London: The Hakluyt Society. 81-168.

CARLHEIM-GYLLENSKÖLD, V. 1900. På åttionde breddgraden. Stockholm: Albert Bonniers Förlag.

CHYDENIUS, K. 1865. Svenska expeditionen till Spetsbergen år 1861 under ledning av Otto Torell. Stockholm: P.A. Norstedt \& Söner.

COLLETT, R. 1911-12. Norges Hvirveldyr. Vol. 1. Norges pattedyr. Kristiania: H. Aschehoug \& Co. (W. Nygaard).

EDGE; T. 1609-22. A breife Discoverie of the Northerne Discoveries of Seas, Coasts and Countries, delivered in order as they were hopefully begunne, and have ever since happily beene continued by the singular industrie and charge of the Worshipfull Society of Muscovia Merchants of London, with the ten severall Voyages of Captaine Thomas Edge the Author. Reprinted diary in Purchas, S. 1906. Hakluytus Posthumus or Purchas His Pilgimes. Vol. 13. Glasgow: James MacLehose and Sons. 4-34.

EIDE, H. 1936. Tilsjøs under Napoleonskrigene. Oslo: H. Aschehoug \& Co. (W. Nygaard).

ESCHELS, P. 1836. Eine Reise nach dem Eis. Unpubl. diary. Norwegian Polar Research Institute Library, Diary \#176. Available at Norsk Polarinstitutt, Middelthuns gate 29, Postboks 5072 Majorstua, N-0301 Oslo, Norway.

ETTE, H. 1930. Døden paa 80 graden. En selvoplevet Arktisk Robinsonade. Vestmanhavn: Ettes Forlag.

FAY, F.H. 1981. Walrus Odobenus rosmarus (Linnaeus, 1758). In Ridgeway, S.H., and Harrison, R.J., eds. Handbook of Marine Mammals. Vol. 1: The walrus, sea lions, fur seals and sea otter. London: Academic Press. 1-23.

FOTHERBY, R. 1613. A Short Discourse of a Voyage made in the Yeare of Our Lord 1613, to the Late Discouered Countrye of Greenland; and a Briefe Discription of the same Countrie, and the Comodities ther raised to the Adventurers. Reprinted diary in: Markham, C.R. 1881. The voyages of William Baffin 1612-1622. London: The Hakluyt Society. 54-79.

1614. A Voyage of Discouerie to Greenland, etc., Anno 1614. Reprinted diary in: Markham, C.R. 1881. The voyages of William Baffin 1612-1622. London: The Hakluyt Society. 80-102.

GERRITSZ, H. 1613. History of the country called Spitsbergen. Its discovery, its situation, its animals. Reprinted diary in: Conway, W.M. 1904. Early Dutch and English voyages to Spitsbergen in the seventeenth century. Hakluyt Society, Second Series, No. 11. London: The Hakluyt Society. 1-38.

GLEN, A.R., and CROFT, N.A.C. 1937. Under the Pole Star. London: Methuen Publishers.

GODFREY, A.S.T. 1938. The cradle of the North Wind. London: Methuen \& Co.

GOVERNOR OF SVALBARD FAUNA-DATA-BASE. 1987-91. N-9170 Longyearbyen, Norway.

HAGERUP, J. 1901. Unpubl. diary. Arctic Society (Tromsø), Polarmuseet Arkiv P.A. 55. Available at Arktisk Forening, Polarmuseet, 9000 Tromsø, Norway.

HAMBERG, A. 1894. En resa till norra Ishafvet sommaren 1892. Ymer $14: 25-61$.

HANSEN, E. 1913. Unpubl. diary. Norwegian Polar Research Institute Library, Diary \#6. Available at Norsk Polarinstitutt, Middelthuns gate 29, Postboks 5072 Majorstua, N-0301 Oslo, Norway.

HANSEN, O. 1882-1912. Erindringer 1882-1912. Unpubl. diary. Norwegian Polar Research Institute Library, Diary \#175. Available at Norsk Polarinstitutt, Middelthuns gate 29, Postboks 5072 Majorstua, N-0301 Oslo, Norway.

HOEL, A. 1931. Kong Karls Land opdaget 6 år tidligere enn man har antatt. Tønsbergskipperen E. Eriksens merkelige opdagelse. Aftenposten 7. July 1931 .

1944. Nord-Norske fangstfolk som geografiske oppdagere og forskere i de arktiske egne. Hảlogalandsambandets Årbok 1944. 1949. Ishavsfangst - fangstnæring in: Strøm, J. Norsk fiskeri og fangst håndbok. Alb. Cammermeyers Forlag, Oslo.

1966. Svalbard I-III. Svalbards historie 1596-1965. Sverre Kildahls boktrykkeri, Oslo.

HORN, G. 1930. Franz Josef Land: Natural history, discovery, exploration, and hunting. Skrifter om Svalbard og Ishavet 29.

HUDSON, H. 1607. Divers Voyages and Northerne Discoveries of that worthy irrecoverable Discoverer Master Henry Hudson. His Discoveries toward the North Pole, set forth at the charge of certaine Worshipfull Merchants of London, in May 1607 . Written partly by John Playse one of the company, and partly by $\mathrm{H}$. Hudson. Reprinted diary in Purchas, S. 1906. Hakluytus Posthumus or Purchas His Pilgimes. Vol. 13. Glasgow: James MacLehose and Sons. 294-313.

INSTITUTE OF MARINE RESEARCH MARINE MAMMALS-DATABASE. 1967-91. P.O. Box 1870 Nordnes, N-5024 Bergen, Norway. ISACHSEN, G. 1919. Fra ishavet. Ishavsfarer Sivert Tobiesen. Folk, fangst og færder. Norske Geografiske Selskabs Aarbok 1916-1919.

IVERSEN, T. 1941. Ishavsøya Hopen. Naturen 65:257-265.

JEPSEN, P.U. 1986. Svalbard - hvalfangst og jagt i Arktis. Bygd $17(1): 1-31$.

JOHANSEN, A. 1932-34. Unpubl. diary. Norwegian Polar Research Institute Library, Diary \#121. Available at Norsk Polarinstitutt, Middelthuns gate 29, Postboks 5072 Majorstua, N-0301 Oslo, Norway.

JOHANSSON, $\AA$. 1975. Valrossen har kommit tillbaka till Spetsbergen. Fauna och Flora (Stockholm) 70:143-144.

KEILHAU, B.M. 1831. Reise i Öst-og Vest-Finmarken samt til BeerenEiland og Spitsbergen, i aarene 1827 og 1828. Christiania: Johan Krohn.

KOLTHOFF, G. 1901. Till Spetsbergen och Nordöstra Grönland år 1900. Stockholm: Fr. Skoglunds Förlag.

1903. Bidrag till kännedom om Norra Polartrakternas däggdjur och fåglar. Kongl. Svenska Vetenskaps-Akademiens Handlingar 36(9):1-104.

KRAMER, W. 1895-1916. Blant hvalros sæl og bjørn i 32 aar. Unpubl. diary. Norwegian Polar Research Institute Library, Diary \#132. Available at Norsk Polarinstitutt, Middelthuns gate 29, Postboks 5072 Majorstua, N-0301 Oslo, Norway.

1922. Unpubl. diary, Norwegian Polar Research Institute Library, Diary \#133. Available at Norsk Polarinstitutt, Middelthuns gate 29, Postboks 5072 Majorstua, N-0301 Oslo, Norway.

1924. Unpubl. diary. Norwegian Polar Research Institute Library, Diary \#134. Available at Norsk Polarinstitutt, Middelthuns gate 29, Postboks 5072 Majorstua, N-0301 Oslo, Norway.

KRAWCZYK, A., and WESLAWSKI, J.M. 1987. Remarks on the past and recent records of walrus, Odobenus rosmarus rosmarus L. 1758 , from South Spitsbergen coasts. Polish Polar Research 8:135-143.

KRISTIANSEN, E.H. 1989. Ishavsfart fra Gratangen og Gamle Ibestad. Alta: (Published privately, ISBN 82-992012-0-9), Alta. $126 \mathrm{p}$.

KÜKENTHAL, W. 1890 . Bericht über die von der Geographischen Gesellschaft in Bremen im Jahre 1889 veranstaltete Reise nach Ostspitzbergen (Dr. Kükenthal und Dr. Walter). Petermann's Geographischen Mittheilungen 1890(3):61-75.

LAMONT, J. 1860. Notes about Spitsbergen in 1859. Proceedings of the Geological Society 1860 March:428-444.

1861. Seasons with the sea-horses; or sporting adventures in the northern seas. London: Hurst and Blackett.

1876. Yachting in the Arctic Seas or notes of five voyages of sport and discovery in the neighbourhood of Spitzbergen and Novaya Zemlya. London: Chatto and Windus.

LARSEN, T. 1983. Hvalrossen på Svalbard. Svalbardposten 1982/83 28:12.

LODGAARD, J. Chr. 1934. En Lars Hansen'sk skildring fra 1837. Norges Handels og Sjøfartstidende, 17 April 1934.

LØNØ, O. 1972. The catch of walrus (Odobenus rosmarus) in the areas of Svalbard, Novaja Zemlja, and Franz Josef Land. Norsk Polarinstitutt Årbok 1970:199-212.

LUBBOCK, B. 1937. The arctic whalers. Glasgow: Brown, Son and Ferguson Ltd.

LUMHOLTZ, L. 1926. Jægerliv. Oslo: Johannes Bjørnstads Forlag.

MALMGREN, A.J. 1863. Iakttagelser och anteckningar till Finmarkens och Spetsbergens Däggdjursfauna. Öfversättelser af Kungliga Vetenskapsakademien Förhandlingar 2:127-155.

MARTENS, F. 1671. Voyage into Spitzbergen. Reprinted diary in White, A. 1855. A collection of documents on Spitzbergen \& Greenland. London: The Hakluyt Society. 3-140.

MøLLEN, G.U. 1971. Utbredelse og populasjonsundersøkelser av fugl og pattedyr på Kapp Linne, Hopen, Kong Karls Land, Kvitøya, Nordaustlandet og Reinsdyrflya sommeren 1971. Norwegian Polar Research Institute unpubl. report. Available at Norsk Polarinstitutt, Middelthuns gate 29, Postboks 5072 Majorstua, N-0301 Oslo, Norway.

NANSEN, F. 1920. En ferd til Spitsbergen. Kristiania: Jacob Dybwads Forlag.

NATHORST, A.G. 1900. Två somrar i Norra Ishafvet. Stockholm: Bijers Bokförlagsaktiebolag.

NØIS, D. 1960. Litt om fangstlivet på Svalbard i gammel og ny tid. Polarboken 1959-60:94-102. 
NORDERHAUG, M. 1969. Hvalrossens (Odobenus rosmarus) forekomst i Svalbardområdet 1960-1967. Norsk Polarinstitutt Årbok 1967:146-150. NORWEGIAN POLAR RESEARCH INSTITUTE FAUNA-DATA-BASE. 1982-91: P.O. Box 5072 Majorstua, N-0301 Oslo, Norway.

OLSEN, M. 1924. Unpubl. diary. Norwegian Polar Research Institute Library, Diary \#120. Available at Norsk Polarinstitutt, Middelthuns gate 29, Postboks 5072 Majorstua, N-0301 Oslo, Norway.

ØRITSLAND, T. 1973. Walrus in the Svalbard area. IUCN Publications New Series Supplementary Paper 39:59-68.

OXÀS, A. 1925. Unpubl. diary. Norwegian Polar Research Institute Library, Diary \#122. Available at Norsk Polarinstitutt, Middelthuns gate 29, Postboks 5072 Majorstua, N-0301 Oslo, Norway.

1955. Svalbard var min verden. Oslo: H. Aschehoug \& Co. (W. Nygaard).

PARRY, W.E. 1828. Narrative of an attempt to reach the North Pole. London: John Murray.

PAULSEN, H. 1917-22. Diary for the motor-vessel Trio 1917-1922. Unpubl. diary. Norwegian Polar Research Institute Library, Diary \#185. Available at Norsk Polarinstitutt, Middelthuns gate 29, Postboks 5072 Majorstua, N-0301 Oslo, Norway.

PEDERSEN, P. 1907. Unpubl. diary. Arctic Society (Tromsø), Polarmuseet Arkiv P.A. 257. Available at Arktisk Forening, Polarmuseet, 9000 Tromsø, Norway.

PEDERSEN, T. 1912. Unpubl. diary. Norwegian Polar Research Institute, Diary \#40. Available at Norsk Polarinstitutt, Middelthuns gate 29, Postboks 5072 Majorstua, N-0301 Oslo, Norway.

PETERMANN, A. 1872. Die Englisch-Norwegischen Entdeckungen im Nordosten von Spitzbergen, Nordfahrten von Smyth, Ulve, Torkildsen, 19 Juni - 27 Sept. 1871. Petermann's Geographischen Mittheilungen 1872:101-111.

PHIPPS, C.J. 1774. A voyage towards the North Pole undertaken by his majesty's command 1773. London: J. Nourse.

PIKE, A. 1894. Arctic hunting. In: Phillips-Wolley, C., ed. Big game shooting. Vol. II. London: Longmans, Green and Co. 1-21.

1897. A winter in the Eightieth Degree. In: Chapman, A. Wild Norway. London and New York: Edward Arnold. 343-351.

POOLE, J. 1604-09. Divers Voyages to Cherie Iland, in the yeeres 1604, $1605,1606,1608$, 1609. Reprinted diary in: Purchas, S. 1906. Hakluytus posthumus or Purchas his Pilgrimes. Vol. 13. Glasgow: James MacLehose and Sons. 265-293.

1610. A Voyage set forth by the Right Worshipfull Sir Thomas Smith, and the rest of the Muscovie Company, to Cherry Iland: and for a further discoverie to be made towards the North Pole, for the likelihood of a Trade or passage that way, in the Ship called the Amitie, of burthen seventie tuns; in the which I Jonas Poole was Master, having fourteene men and one boy AD 1610. Reprinted diary in: Purchas, S. 1906. Hakluytus posthumus or Purchas His Pilgrimes. Vol. 14. Glasgow: James MacLehose and Sons. 1-23.

1611. A briefe Declaration of this my Voyage of discovery to Greenland, and towards the West of it, as followeth: being set forth by the right Worshipfull Sir Thomas Smith, Governour of the right Worshipfull Company of new Trades, \&c. Reprinted diary in: Purchas, S. 1906. Hakluytus posthumus or Purchas His Pilgrimes. Vol. 14. Glasgow: James MacLehose and Sons. 34-41.

1612. A Relation written by Jonas Poole of a Voyage to Greenland, in the yeere 1612, with two ships, the one called the Whale; the other the Seahorse, set out by the Right Worshipfull the Muscovie Merchants. Reprinted diary in: Purchas, S. 1906. Hakluytus posthumus or Purchas His Pilgrimes. Vol. 14. Glasgow: James MacLehose and Sons, 41-47.

REEVES, R.R. 1978. Atlantic walrus (Odobenus rosmarus rosmarus): A literature survey and status report. United States Departement of the Interior Wildlife Research Report $10.41 \mathrm{p}$.

REHFUS-OBERLÄNDER, C. 1941. In arktischer Wildnis. Jagden auf Eisbären und Grossrobben. München: F.C. Mayer Verlag.

RÖMER, F., and SCHAUDINN, F. 1900. Plan des Werkes und Reisebericht. II. Die landtiere und die Eistiere. Fauna Arctica 1:1-84.

SÆTHER, C.S. 1929. Unpubl. letter to Adolf Hoel concerning Norwegian sealing at Viktoria Island. Norwegian Polar Research Institute Library. Available at Norsk Polarinstitutt, Middelthuns gate 29, Postboks 5072 Majorstua, N-0301 Oslo, Norway.

SCHARE, C. 1837 . Kort beskrivelse av vort ophold paa Spidsbergen fra 3die September 1834 til den 22de Juni 1835. Norsk Handelstidende 1837 (10 May):1261-1263.

SCORESBY, W. 1820. An account of the Arctic regions with a description of the Northern whale-fishery. Edinburgh: Archibald Constable \& Co. .1823. Journal of a voyage to the Northern whale-fishery; including researches and discoveries on the eastern coast of West Greenland, made in the summer of 1822, in the ship Baffin of Liverpool. Edinburgh: Archibald Constable and Co.

SøRENSEN, L.N. 1958. Henry Rudi, Isbjørnkongen. Oslo: Gyldendal Norsk Forlag.

SOUTHWELL, T. 1898. Notes on the seal and whale fishery, 1897. Zoologist 4(2):69-77.

SVENDSEN, A. 1927. Unpubl. diary. Norwegian Polar Research Institute Library, Diary \#74. Available at Norsk Polarinstitutt, Middelthuns gate 29, Postboks 5072 Majorstua, N-0301 Oslo, Norway.

1928. Unpubl. diary. Norwegian Polar Research Institute Library, Diary \#66. Available at Norsk Polarinstitutt, Middelthuns gate 29, Postboks 5072 Majorstua, N-0301 Oslo, Norway.

1930. Unpubl. diary. Norwegian Polar Research Institute Library, Diary \#68. Available at Norsk Polarinstitutt, Middelthuns gate 29, Postboks 5072 Majorstua, N-0301 Oslo, Norway.

TOLLÉN, E. 1960. Däggdjur och fåglar på Nordaustlandet, Spetsbergen. Fauna och Flora (Stockholm) 55(3-4):79-96.

WELLS, J.C. 1876. The gateway to the Polynia. A voyage to Spitzbergen. London: Henry S. King \& Co.

YTREBERG, N.A. 1946. Tromsø bys historie. Oslo: Tell Forlag.

ZORGDRAGER, C.G. 1720. Bloeyende opkomst der Aloude en hedendaagsche Groenlandsche visschery. Amsterdam: Johannes Ossterwyk. 